\title{
USA efter midtvejsvalget
}

\section{Michael Ehrenreich}

\section{Valget i november vil få markante konsekvenser, men midtvejsvalget kan ikke bruges som pejle- mærke for præsidentvalget i 2012, hvor Barack Obama alligevel er storfavorit}

Stemningen i amerikansk politik skifter så hurtigt i vor tid, at man skal være varsom med at træffe for vidtgående, fremadrettede konklusioner, når pendulet svinger. Desværre bliver dette enkle råd ikke altid fulgt, hvilket der i de senere år har været flere eksempler på.

I november 2004, da præsident George W. Bush netop var blevet genvalgt med republikansk kongresflertal i ryggen, talte man i USA om den permanente ændring i amerikansk politik. Begrebet var blevet skabt af præsidentens nære medarbejder Karl Rowe, og det gik ud på, at det demokratiske partis historiske dominans skulle bringes til afslutning. Efter genvalget havde mange den opfattelse, at Rowes mål så ud til at være opnået.

Men den permanente ændring varede kun to år. I 2006 generobrede demokraterne flertallene i såvel Senatet som Repræsentanternes Hus, og lagt sammen med Bushs dalende popularitet stod det klart, at der var en kraftig bevægelse i gang den modsatte vej. Bevægelsen i retning af demokraterne var med til at sikre Barack Obama sejren ved præsidentvalget i 2008.

Også ved denne lejlighed blev der brugt store ord. Det republikanske parti blev i amerikansk presse hængt ud som 'udryddelsestruet', og der blev spekuleret $i$, at partiet skulle bruge en generation eller mere for at komme tilbage. Republikanerne måtte, blev det sagt, opfinde helt nye politiske budskaber og i hvert fald møde med nye frontfigurer for at generobre scenen.

Midtvejsvalget i november 2010 skød alle disse forudsigelser ned. Igen varede det kun to år, før pendulet svingede tilbage i republikanernes retning, og såvel deres politiske budskab som deres frontfigurer var de samme som tidligere. 
Det nye i amerikansk politik er ikke, at stemningen skifter. Det nye er, at mens det før varede ti eller tyve år at bevæge sig fra en demokratisk til en republikansk periode eller omvendt, så er intervallerne nu reduceret til et par år.

Konsekvenserne af den massive øretæve til demokraterne i november med tabet af flertallet i Repræsentanternes Hus og en stor tilbagegang i Senatet skal vurderes i dette lys. Midtvejsvalget vil få markante konsekvenser for den politiske udvikling i Washington i de kommende år. Men valgresultatet kan ikke bruges som pejlemærke for præsidentvalget i 2012 endsige for amerikansk politik længere frem.

Tre hovedkonsekvenser af valget ligger lige for. For det første er perioden med store reformer formentlig forbi. Præsident Obamas første par år ved magten var ekstraordinært produktive med gennemførelsen af de store økonomiske hjælpepakker i foråret 2009, sundhedsreformen og reguleringen af finanssektoren som de mest fremtrædende eksempler.

Men der mangler stadig en del fra hans oprindelige program. Først og fremmest en klimalov og en udgiftsreform, der skal bringe en række offentlige ydelser under kontrol og gøre dem mindre belastende for de offentlige budgetter. Ingen af de initiativer vil kunne gennemføres efter midtvejsvalget.

Sagligt set er der en ægte uenig- hed mellem partierne. Eksempelvis er der på klimaområdet blandt republikanerne udbredt skepsis over for, hvorvidt klimaforandringerne er reelle og menneskeskabte, mens det modsatte gør sig gældende hos demokraterne.

Politisk har de styrkede republikanske grupper i begge Kongressens kamre ingen som helst interesse $i$ at hjælpe præsidenten med at få flere elementer fra hans program gennemført. Tværtimod er deres politiske interesse at gøre livet så surt som muligt for manden i Det Hvide Hus. Denne interesse vil være stigende, efterhånden som forberedelserne til præsidentvalgkampen ruller i gang fra foråret.

I stedet for at se fremad, kan Obama få nok at gøre med beskytte sine landvindinger. Den republikanske ledelse gik til valg på at ophæve sundhedsreformen, og selvom der ikke er megen udsigt til, at det vil ske, eftersom demokraterne har bevaret flertallet i Senatet, og en ophævelse under alle omstændigheder kan bremses med et veto fra præsidenten, vil en sådan proces vække stor debat og kræve mange kræfter i Det Hvide Hus.

Alene i kraft af flertallet i Repræsentanternes Hus vil republikanerne kunne forsinke implementeringen af sundhedsreformen, der er planlagt til at skulle ske gradvist over en årrække. I det amerikanske system starter udmøntningen af udgiftslove i Huset, og dette giver det republi- 
kanske flertal betydelige muligheder for at obstruere indkøringen af den meget omfattende reform.

Noget lignende gør sig i øvrigt gældende i næste led af implementeringen af reformen. Ved guvernørvalgene, der fandt sted samme dag som midtvejsvalget, skiftede mange poster i delstaterne fra demokrater til republikanere. Også dette vil blive en hovedpine for Obama, fordi reformen lokalt vil støde ind i større modstand.

\section{Høringer vender tilbage}

Den anden hovedkonsekvens af valget drejer sig om et fænomen, som man næsten ikke har set noget til i de forløbne to år, fordi der har været overensstemmelse mellem præsidentens parti og flertallene i begge kongreskamre. Det drejer sig om høringer.

Eftersom republikanerne nu kontrollerer Huset, kan de iværksætte høringer rettet imod enkelte elementer af præsidentembedets arbejde. Og ikke nok med det. De kan forlange dokumenter udleveret fra Det Hvide Hus og ministerierne og tvinge såvel ministre som regeringsembedsmænd til at stille op til offentlige forhør på Capitol Hill.

Disse høringer skal ikke undervurderes, selvom de ofte betegnes som politisk teater. Høringerne vil betyde, at præsidenten og hans medarbejdere skal bruge tid og kræfter på nogle processer, som man ikke skul- le bekymre sig om tidligere. Det vil alt andet lige tappe energi og politisk kapital fra det fremadrettede arbejde.

I en bredere sammenhæng vil høringerne indebære, at præsident Obama mister sin næsten totale dominans i USA's landspolitiske debat. Høringer er godt stof i pressen, og de vil betyde, at præsidenten får et modspil i den offentlige meningsdannelse på landsplan, som han ikke har haft tidligere.

Hvor langt vil republikanerne gå? De lægger ikke skjul på, at de vil bruge dette nye våben mod Obama, men siger at det vil ske med omtanke. Det bedyres, at man ikke vil se en gentagelse af Kongressens efterforskning i slutningen af 1990'erne af præsident Bill Clintons sexliv. Frygten for, at befolkningen vil vende sig imod det, er overhængende. Men i Washington venter man med spænding på, hvor snittet lægges.

Den tredje hovedkonsekvens af valget skal ses i relation til den langsigtede udvikling, som USA's politiske system i almindelighed og de to store politiske partier i særdeleshed gennemløber.

Vi er vant til at betragte republikanere og demokrater som mange partier i to forklædninger. Demokraterne havde i mange år to hovedfløje - en ganske konservativ fløj, som havde hjemme i sydstaterne, og en anden fløj til venstre for midten i det nordøstlige USA og ude vestpå, først og fremmest i Californien. 
Også republikanerne havde tidligere forskellige fløje, og begge partier havde i øvrigt ofte svært ved at enes internt. Men i takt med at specielt det republikanske parti gennem de seneste 30 år har oplevet langsigtet vækst, er det blevet mere ideologisk. Republikanerne er i dag mere solidt placeret til højre, mens demokraterne har mistet en stor del af deres konservative fløj og er mere tydeligt forankret til venstre.

Midtvejsvalget blev en klar fortsættelse af denne udvikling. Mange af de demokrater, der tabte, var konservative demokrater. Deres pladser i Kongressen overtages nu af republikanere. Set i det lange lys er midten forsvundet i det republikanske parti og er godt i gang med at forsvinde hos demokraterne. Den politiske forskel mellem partierne forstærkes, og det vil yderligere øge polariseringen i amerikansk politik.

Obamas vigtigste valgløfte under valgkampen i 2008 drejede sig om, at han kunne bringe denne polarisering til ophør. Og det gav genlyd blandt det store flertal af amerikanerne, som ikke er stærkt ideologisk funderede, som er trætte af de stadige slagsmål og den udbredte mudderkastning i Washington, og som ønsker partipolitisk samling om løsningen af USA's største problemer.

Men løftet er ikke blevet indfriet. Tværtimod har tonen mellem partierne i de forløbne år sjældent været skarpere i takt med, at den republikanske opposition har haft stort held med at holde sammen på partigrupperne i begge Kongressens kamre om en næsten total afvisningsfront over for udspil fra præsidenten.

Med et republikansk parti, der nu vejrer morgenluft med henblik på præsidentvalget i 2012, vil tonen formentlig blive endnu skarpere. Obamas valgløfte om at kaste de ideologiske grøfter til og udvirke tværpolitiske løsninger vil fortone sig yderligere.

De to partier vil formentlig støde hårdest sammen på to bestemte områder, nemlig skattepolitikken og finansloven. På det skattemæssige område er situationen den, at præsident Bushs ti-årige skattelettelser udløb ved årsskiftet. Republikanerne ønsker dem forlænget for alle skatteydere, mens demokraterne kun vil forlænge dem for familier med indtægter på under 250.000 dollar.

\section{Tea Party}

Debatten om finansloven vil blive særligt interessant at følge, fordi det bliver på dette område, at man formentlig vil se de nyvalgte repræsentanter fra Tea Party-bevægelsen markere sig særligt. Samspillet mellem disse politikere og den republikanske partiledelse vil blive retningsgivende for den linje, som partiet overordnet vil lægge i forhold til Obama.

Tea Party er en meget bred græs- 
rodsbevægelse. Den har sit udspring på højrefløjen i amerikansk politik, men den repræsenterer et utal af synspunkter på enkeltområder, som ikke er koordinerede, endsige under nogen kontrol fra centralt hold.

Nogle principper er alle i bevægelsen imidlertid enige om, nemlig mindre magt til staten, lavere skatter og en sænkning af de offentlige udgifter. Derfor er det forventningen, at det bliver i debatten om finansloven, hvor ovennævinte begreber jo bliver konkrete, at man vil se Tea Party-bevægelsens nye politikere markere sig på Capitol Hill.

Den nye formand for Repræsentanternes Hus, John Boehners instinkt vil være at undgå en konfrontation med Det Hvide Hus. Han husker kun alt for godt, hvordan republikanerne i midten af 1990'erne i den offentlige opinion tabte en konfrontation med præsident Clinton om finansloven, hvorunder man to gange måtte lukke store dele af det føderale statsapparat, fordi den forrige finanslov var udløbet, og der derfor ikke var penge til driften.

Republikanerne havde i 1994 vundet en massiv sejr ved et midtvejsvalg, hvor man erobrede flertallene i begge Kongressens kamre. Under ledelse af den meget ideologiske formand for Huset, Newt Gingrich, kastede man sig ud i konfrontationen med Clinton, men den ses i dag som én af årsagerne til, at Clinton efter nederlaget ved midtvejsvalget kæmpede sig tilbage og blev gen- valgt til præsidentposten i 1996.

Velvidende, at meningsmåling efter meningsmåling viser, at det store flertal af amerikanerne forlanger politiske resultater frem for ideologiske markeringer, vil John Boehner forsøge at trække en grænse for et sammenstød med Obama på finanspolitikken. Han vil med rette frygte beskyldninger fra brede kredse i vælgerkorpset for at overreagere og overfortolke strømpilen fra valget i november, hvis republikanerne går for langt.

Men vil Tea Party-folkene acceptere at blive holdt i stramme tøjler? Eftersom bevægelsen af natur er populistisk, og mange af de nyvalgte vil opfatte deres mandat som meget offensivt, er det langt fra sikkert, at de vil betragte en lignende konfrontation som i 1990'erne som nogen dårlig ting. Mange af disse politikere vil mene, at det vil være godt for det republikanske parti at fremhæve forskellene til demokraterne.

\section{Lammelse i Washington}

Den overordnede republikanske linje i Kongressen vil ikke kun blive afgjort af samspillet mellem partiledelsen og Tea Party-bevægelsens nyvalgte politikere. Også den begyndende valgkamp forud for præsidentvalget i 2012 vil spille ind.

Viser det sig, hvad mange forventer, at den tidligere guvernør i Alaska og vicepræsidentkandidat Sarah Palin i løbet af 2011 begynder at 
markere sig konkret med henblik på et kandidatur, vil det influere på samarbejdsmiljøet på Capitol Hill og formentlig trække partierne yderligere fra hinanden.

De fleste iagttagere i Washington venter, at lovgivningsprocessen vil blive lammet på de store områder. På enkelte felter vil der kunne etableres et samarbejde, men hvor det virkelig betyder noget, vil partierne stå stejlt over for hinanden.

Ud over, at der som allerede nævnt ikke vil kunne vedtages nye reformer, bliver en af konsekvenserne, at der sandsynligvis ikke kan opnås enighed om en flerårig aftale om nedbringelse af det hastigt voksende amerikanske statsunderskud. Der vil heller ikke kunne vedtages nye økonomiske hjælpepakker, hvis amerikansk økonomi fortsætter med at hive efter vejret.

For statsunderskuddets vedkommende og set i en snæver partipolitisk optik behøver denne udvikling ikke kun være en ulempe for præsident Obama. Snarere tværtimod. Sammenlignet med situationen i de forløbne to år, hvor præsidenten og hans partifæller i Kongressen har haft hele det politiske ansvar, vil republikanerne i den kommende tid få et politisk medansvar for udviklingen.

Nogle mener ligefrem, at præsidenten skal gøre en dyd af nødvendigheden og føre valgkamp imod Kongressen. Det er gjort tidligere og med held. Mest tydeligt i 1948, da demokraten Harry Truman gjorde emnet til et af de centrale elementer i en valgkamp, hvor han gang på gang rettede hårde anklager mod 'the Do Nothing Congress', som han kaldte den. Efter at have været undertippet i løbet af valgkampen endte han med at trække det længste strå.

\section{Hvad gør Obama?}

Hvad vil Obama gøre? Hvilke konkrete konklusioner vil han drage af det demokratiske partis nederlag? Vil han ændre politisk kurs, eller vil den hidtidige linje blive fastholdt? Nyere fortilfælde trækker i forskellige retninger. I 1982, da Ronald Reagan ved sit første midtvejsvalg havde ført det republikanske parti ud i et nederlag, om end i mindre omfang, søgte han samarbejde med demokraterne på forskellige områder, men den overordnede linje blev fastholdt.

I 1994 ændrede Bill Clinton politik, efter at demokraterne mistede flertallene i såvel Senatet som Repræsentanternes Hus. Sidstnævnte for første gang i et halvt århundrede, så der var tale om et næsten katastrofalt nederlag.

Mens Clinton som nævnt tog konfrontationen med sine modstandere om finansloven, kom han dem samtidig i møde. Han erklærede med en senere meget berømt bemærkning, at "the era of big government is over". Han indgik også et forlig med 
republikanerne om en velfærdsreform, som mange i hans eget parti anså for et decideret forræderi mod det demokratiske partis sjæl og identitet. Der var tale om tydeligt og klart sving til højre.

Hvorvidt Obama kan gøre noget lignende er tvivlsomt. Hans politiske udgangspunkt ligger et andet sted. Inden Clinton blev præsident, var han guvernør i Arkansas, hvor han i øvrigt stammer fra, så hans geografiske udgangspunkt var altså det konservative Syden. Senere blev han en af frontfigurerne i den midtsøgende demokratiske organisation Democratic Leadership Council, så han erobrede partiets nominering som præsidentkandidat fra en position $\mathrm{i}$ midten. Med denne baggrund kunne Clinton efter nederlaget i 1994 bevæge sig mod højre med troværdigheden i behold.

Obama kommer fra venstrefløjen i det demokratiske parti, og som medlem af Senatet stemte han markant til venstre for midten i amerikansk politik. Hertil kommer, at partierne som nævnt er blevet mere ideologisk entydige, hvilket også vil gøre det sværere for den nuværende præsident at 'lave en Clinton' ind over midten i amerikansk politik.

På demokraternes venstrefløj er man i dag langt fra begejstrede for Obama, når man ser bort fra tilslutningen fra den sorte befolkningsgruppe, som fortsat er rekordhøj. Han anklages for at være for tilbageholdende i det ideologiske opgør med republikanerne, og der er en udbredt fornemmelse af svigt over for partiets idealer, efter at præsidenten besluttede at sende flere tropper til Afghanistan.

Kritikken fra venstrefløjen sætter grænser for Obamas manøvremuligheder, og han er nødt til at tage den alvorligt. Erfaringen viser, at udfordres en siddende præsident internt $\mathrm{i}$ partiet, kan det blive dødbringende for hans muligheder for at blive genvalgt.

New York Times bragte i efteråret en interessant opgørelse, der viste, at de seneste fire præsidenter, som ikke opnåede genvalg, alle blev udfordret inden for deres eget parti. Demokraten Lyndon Johnson var i 1968 nær ved at tabe et tidligt primærvalg til Eugene McCarthy og opgav kort efter. Republikaneren Gerald Ford besejrede internt Reagan i 1976, men tabte præsidentvalget til Jimmy Carter. Fire år senere blev Carter udfordret af Edward Kennedy og tabte siden til Reagan. I 1992 måtte George Bush Senior bruge kræfter på først at besejre Patrick Buchanan, inden han selv tabte til Clinton.

At Obama vil få en intern modstander fra det demokratiske parti, forekommer på nuværende tidspunkt usandsynligt. Det er i denne forbindelse værd at minde om, at han trak sin værste rival fra 2008 , Hillary Clinton, ind i regeringen som udenrigsminister. Kommer han i meget alvorlig modvind i det næste 
års tid, kan det vise sig at være et endnu større politisk mesterstykke end hidtil antaget.

\section{Obama storfavorit i 2012}

På tidspunktet for færdiggørelsen af denne artikel havde Obama endnu ikke givet signaler om, hvordan han konkret vil reagere på resultatet af midtvejsvalget. Det mest almindelige gæt var, at han i princippet vil fastholde sin politiske kurs. Han vil erkende, at der ikke kan gennemføres store reformer, men han vil søge samarbejde med republikanerne på enkeltområder, som ligger uden for det politiske minefelt, i håb om at det kommende år ikke bliver helt indholdsløst på lovgivningsområdet.

Desuden vil Obama benytte præsidentembedets gennemslagskraft maksimalt i den offentlige debat. Selvom han som nævnt mister sin totale dominans, er der ingen andre på den amerikanske offentlige scene, der kan tiltrække sig så stor opmærksomhed som præsidenten. Denne tiltrækningskraft vil han bruge til at forsøge at dreje debatten i en retning, der fremmer hans egne muligheder for genvalg.

Man vil høre ham tale meget mere om økonomi og specielt jobskabelse. Den svage vækst i økonomien og den fortsat høje arbejdsløshed var hovedårsagen til valgnederlaget, og præsident Obama har åbent erkendt, at han selvom han faktisk gjorde meget på det økonomiske område i sine første år ved magten, så var det ikke indtrykket blandt mange vælgere. Det bliver i det hele taget økonomien, og særligt udviklingen $i$ arbejdsløshedstallene, der bliver den afgørende faktor ved præsidentvalget om to år. Sådan har det været ved mange tidligere præsidentvalg, og det bliver også tilfældet næste gang.

Retter økonomien sig, hvad der er den almindelige forventning, vil Obama være overvældende favorit til genvalg. Der skal overordentlig meget til, før amerikanerne nægter en siddende præsident at få endnu en embedsperiode. Er økonomien i vækst, sker det stort set aldrig. Det er derfor værd at minde om, at udfaldet af valget det følgende år vil afhænge mindre af, hvem der bliver Obamas modstander, end af udviklingen i økonomien helt frem til november 2012.

Retter amerikansk økonomi sig ikke, og indtræder der tværtimod en forværring, vil det forholde sig anderledes. Præsidentvalget bliver langt mere åbent. Måske vil det endda vise sig, at den vending i amerikansk politik, der viste sig ved midtvejsvalget i november, bliver af mere varig karakter.

Michael Ehrenreich er medredaktør på Kristeligt Dagblad og udenrigspolitisk kommentator. Han er tidligere udlandskorrespondent $i$ Washington. 